\title{
Removal Efficiency of Chemical Oxygen Demand on Greywater using Multi Soil Layering (MSL) Technology
}

\author{
Syafrudin $^{{ }^{*}}$, Mochtar Hadiwidodo ${ }^{1}$, Irawan Wisnu Wardhana ${ }^{1}$, Tika Ayu Kusuma \\ Wardani ${ }^{1}$, Indah Sekar Arumdani ${ }^{1}$, Sudarno ${ }^{1}$, Nurandani Hardyanti ${ }^{1}$
}

'Environmental Engineering Department, Faculty of Engineering, Universitas Diponegoro, Jl. Prof. Soedarto, SH, Kampus Undip Tembalang, Semarang, Indonesia 50275

*Corresponding author, email: syafrudin@lecturer.undip.ac.id

\begin{abstract}
Greywater is household waste sourced from kitchens and bathrooms, except for toilets. Around 58\%$85 \%$ of greywater can be generated from the total volume of household wastewater per house. It is necessary to treat wastewater before it is discharged into water bodies to prevent the adverse effects of contaminants on the environment and human health while reducing the demand for clean water. However, due to environmentally friendly, socially sustainable, and economical treatment costs, considering that greywater is produced every day and continuously, Multi Soil Layering (MSL) technology can be an alternative to remove contaminants in water. Thus, this study aims to determine the migration of COD in greywater using MSL technology. Other parameters tested were $\mathrm{pH}$ and temperature by taking samples of wastewater in residential areas of Semarang City. In this study, there are two stages, namely the preliminary stage and the running stage. The MSL system will use three reactors with andosol soil, apus bamboo, and coconut shell activated charcoal as mixed soil blocks (SMB). Reactor A (activated charcoal and andosol soil), reactor B (bamboo apus and andosol soil), reactor C (andosol soil, bamboo apus, activated charcoal). The results of domestic wastewater treatment using the MSL method in each of the three reactors could remove COD by $75 \%, 74 \%$, and $76 \%$. Reactor $C$ obtained the highest COD removal efficiency compared to other reactors.
\end{abstract}

Keywords: chemical oxygen demand, domestic wastewater, multi soil layering system

\section{Introduction}

The increase in population is proportional to the rise in household wastewater generated for daily activities. This study will discuss greywater. According to Asano et al. (2007), greywater is household waste sourced from kitchens and bathrooms, except toilets. Around 58\%-85\% of greywater can be generated from the total household wastewater per house (Noutsopoulos et al., 2018). In greywater, there is a Chemical Oxygen Demand (COD) content, which according to Rahajeng et al. (2015), the increasing COD content in the water will affect the activity of microorganisms to be more active. This phenomenon is caused by microorganisms requiring oxygen to decompose dissolved organic matter in water. The higher the content of organic substances can cause toxicity to aquatic animals and the marine environment. In addition, according to Santoso (2014), household waste that is directly channeled into water bodies without prior treatment can endanger health, cause foul odors, and reduce aesthetics. 
Therefore, before being discharged into water bodies, it is necessary to treat greywater. According to Eriksson et al. (2002), using greywater by using or recycling it again as irrigation, flushing toilets, and washing can help reduce adverse effects on the environment while reducing the demand for clean water. Wastewater treatment with various technologies has been carried out, such as septic tanks, lagoons, and artificial wetlands (Vymazal and Březinová, 2016, Zhang et al., 2019, An et al., 2016). However, according to Ying et al. (2010), these technologies have drawbacks, requiring a large space depending on low temperatures. In addition, household wastewater treatment with WWTP (Wastewater Treatment Plant) on a household scale has not been implemented due to high operational and maintenance costs (Zaman and Oktiawan, 2020). Therefore, the selected treatment must be environmentally friendly, socially sustainable, and economical in its treatment costs, considering that greywater is produced every day and continuously.

Based on the research of Sato et al. (2011), Ho and Wang (2015), Song et al. (2018); even though the domestic waste treatment technology with complex conditions can be overcome by the Multi Soil Layering (MSL) method, besides this technology is environmentally friendly and requires minimal costs. According to Guan et al. (2014), MSL incurs lower costs, saves land use, and easier maintenance due to the risk of minor clogging. In addition, its operations are more flexible and more durable than other technologies. MSL is composed of mixed soil block (SMB) and permeable layer (PL). Soil plays an essential role in the water treatment process because it is a place for living microorganisms (Ho and Wang, 2015, Guan et al., 2014). Meanwhile, PL acts as a transformer and removes physicochemical substances (Wu et al., 2008). According to Sato et al. (2011), Wei and Wu (2018), MSL works efficiently in removing organic matter. This statement is evidenced by research from Ho and Wang (2015), who treated wastewater using MSL with PL in zeolite capable of removing COD content up to $76 \%$.

Semarang had a population of more than 1.6 million in 2019 and is one of the most populous cities in Indonesia (Anonymous, 2019). This will affect the amount of wastewater generated from daily activities. In addition, there are not many studies related to the application of MSL in wastewater in the city of Semarang. Therefore, this study took wastewater samples in Semarang housing areas and tested the COD, $\mathrm{pH}$, and temperature parameters. Initial test results show that only the COD parameter exceeds the quality standard of the Minister of Environment and Forestry Regulation Number 68 of 2016 concerning Domestic Wastewater Quality Standards. So, this study aims to determine the migration of COD in greywater using MSL technology.

This research will use three reactors with andosol soil, apus bamboo, and coconut shell activated charcoal as mixed soil blocks (SMB). The consideration is because Andosol soil has pore space as a gathering place for microorganisms (Hartemink, 2012). Meanwhile, according to An et al. (2016), activated charcoal absorbs harmful content from wastewater and organic matter as a carbon supply used in the denitrification process. Permeable layer (PL) is used in the form of gravel, zeolite, and silica sand.

\section{Materials and Methods \\ 2.1 Multi Soil Layering System}

The MSL system will use three reactors with andosol soil, apus bamboo, and coconut shell activated charcoal as mixed soil blocks (SMB). Anaerobic conditions can occur when using Andosol soil; as a result, it can reduce the content of organic matter. In addition, the mixture of soil with activated charcoal, which is an organic material according to Wakatsuki (Pawestri et al., 2020), causes an expansion of the surface of the adsorbent and narrowing of the pores. As a result, it can assist in the process of filtration and adsorption of greywater. According to Suci (2017), the addition of zeolite causes an increase in $\mathrm{pH}$, and the adsorption process can run optimally in an acidic environment.

Meanwhile, silica sand and gravel function as filters. SMB and PL are arranged in a reactor measuring $36 \mathrm{~cm} \times 30 \mathrm{~cm} \times 65 \mathrm{~cm}$ with a thickness of $5 \mathrm{~mm}$, as shown in Figure 1. The compositions between reactors are different and can be seen in more detail in Table 1. 
Table 1. Comparison of SMB composition for each reactor

\begin{tabular}{llll}
\hline Reactor & Andosol Soil & Activated Charcoal & Bamboo Apus \\
\hline A & 1 & 1 & \\
B & 1 & & 1 \\
C & 2 & 1 & 1 \\
\hline
\end{tabular}

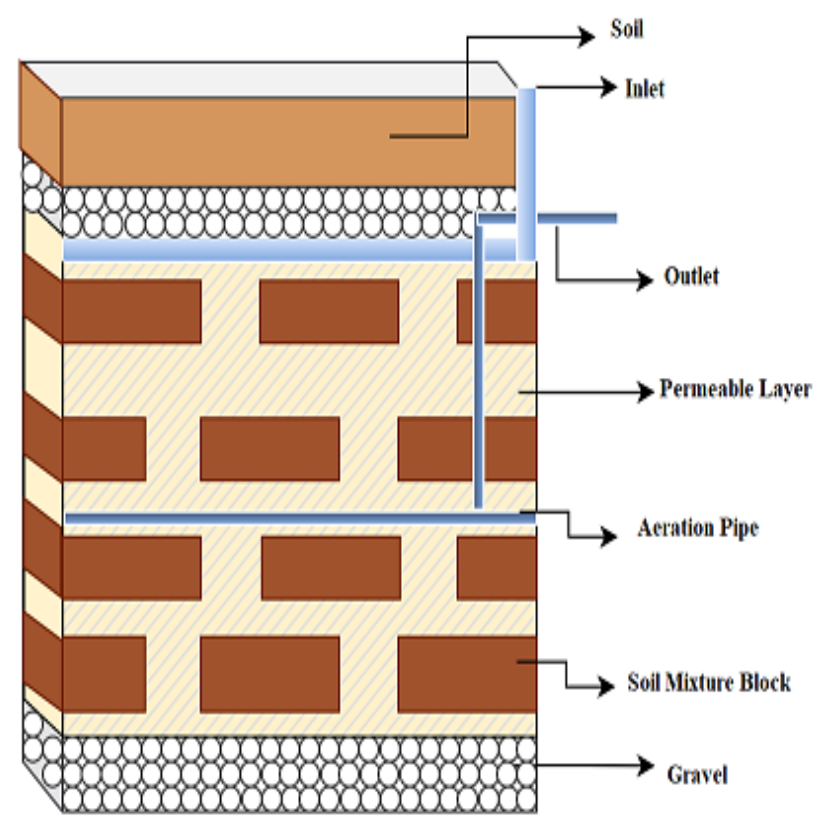

Figure 1. SML reactor diagram

\subsection{Preliminary Stage}

The preliminary stage consists of testing the water sample content and the acclimatization seeding process. Wastewater samples were obtained from grey water for washing and residential kitchens in the Semarang area concerning SNI 6989.59:2008 concerning Procedures for Sampling of Wastewater. Furthermore, the seeding process is carried out using a batch reactor and allowed to stand for 14-24 days. While in the acclimatization process, $\mathrm{COD} \pm 10 \%, \mathrm{pH}$, and temperature were carried out. After the acclimatization process, the hose installation on the reactor effluent will be carried out to maintain the water level balance.

\subsection{Running Stage}

The first stage of this implementation is filtering grey water with a coconut shell filter before sending it to the reservoir. The purpose of this filter is to separate large and small solids. After being accommodated in the reservoir, the greywater flows to the MSL reactor with a capacity of 22 liters within 24 hours. During the 20-day running process, the COD concentration test, which refers to SNI 6989.2-2009 (regarding Procedures for Testing COD with Closed Reflux Spectrophotometry), is carried out once a day first ten days and every two days on the following days. Data processing on COD testing is used to determine COD removal with the formula:

$$
\% \text { COD } \quad=\frac{\text { COD Influent }- \text { COD Efluent }}{\text { COD Influent }} \times 100 \%
$$




\section{Result and Discussion}

\subsection{Grey Water Wastewater Characteristic Test}

The testing of wastewater parameters is presented in Table 2 and compared with the quality standards in the Regulation of the Minister of Environment and Forestry Number 68 of 2016 concerning Domestic Wastewater Quality Standards. Based on the results in the table, only the COD concentration with a value of 1,899.33 mg/l exceeds the quality standard of $100 \mathrm{mg} / \mathrm{l}$. Meanwhile, $\mathrm{pH}$ and temperature are still relatively safe, with values of 6.6 and $29.3^{\circ} \mathrm{C}$. Therefore, the parameter that must be reduced in value to exceed the quality standards is COD.

Table 2. Wastewater test results of Semarang city

\begin{tabular}{lcc}
\hline Parameter & $\begin{array}{l}\text { Quality Standards (Regulation of the Minister of } \\
\text { Environment and Forestry Number 68 Year 2016) }\end{array}$ & Test Results \\
\hline $\mathrm{pH}$ & $6-9$ & 6,6 \\
$\mathrm{COD}$ & $100 \mathrm{mg} / \mathrm{l}$ & $1,899.33 \mathrm{mg} / \mathrm{l}$ \\
\hline
\end{tabular}

\subsection{Seeding and Acclimatization Test Results}

After knowing the characteristics of the water, the next step is seeding and acclimatization. The process that lasts for 14-24 days is carried out so that microorganisms or bacteria attach and grow on SMB. According to Badruz (2020), wastewater is ready to be treated after the grown microorganisms have adapted to the acclimatization stage. With an effluent absorption volume of $20-25 \mathrm{~mL} /$ day and only added grey water at the beginning, more stable results were obtained in reactor C. Reactor A and $\mathrm{B}$ tended to be more fluctuative, but the three reactors received $\mathrm{pH}$ values ranging from $6.1-7.9$ and temperatures between $28.7-32.3{ }^{\circ} \mathrm{C}$. These results are still within the threshold of optimum temperature and $\mathrm{pH}$ of the microorganism activity according to (Tchobanoglus et al., 2003), namely 25 - $35^{\circ} \mathrm{C}$ and $6.5-7.5$. While the COD concentration tends to experience an insignificant decrease, the biological process has not occurred at the beginning of the acclimatization process. The result is depicted in Figures 2 and 3.

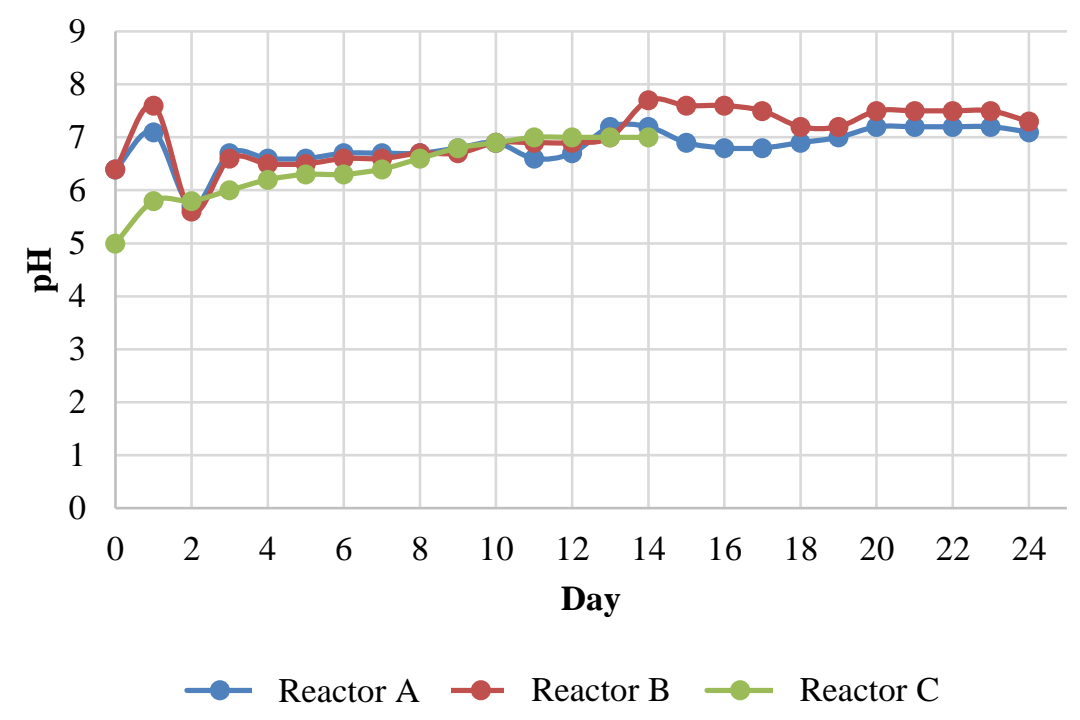

Figure 2. Wastewater $\mathrm{pH}$ during the acclimatization stage 


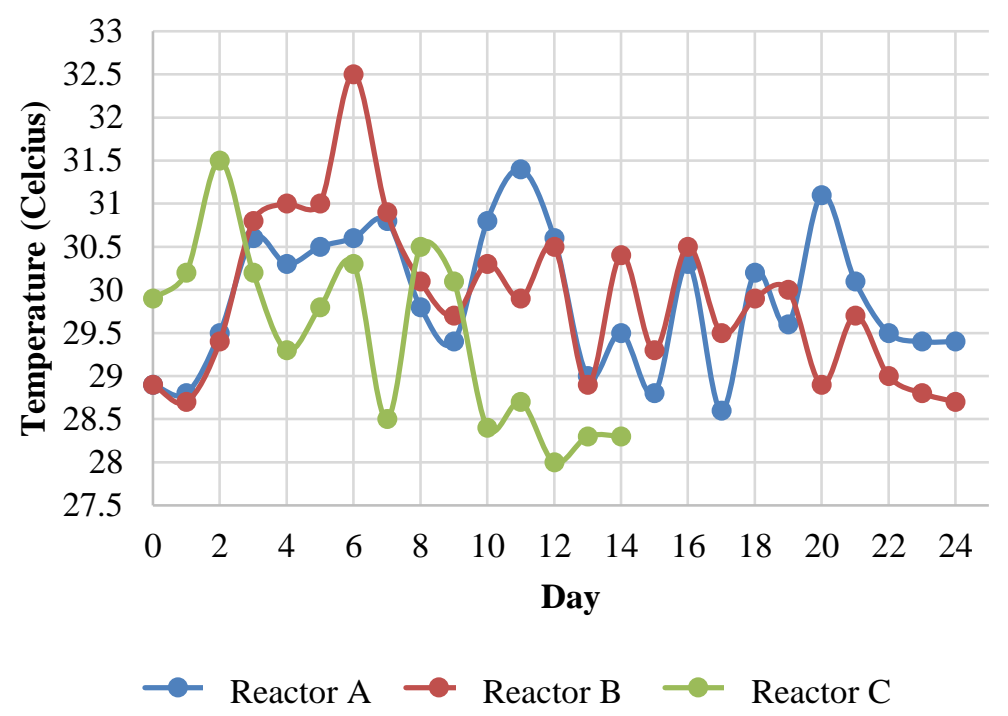

Figure 3. Wastewater temperature during acclimatization stage

\subsection{Running Process Results \\ 3.3.1 $\quad \mathrm{pH}$ and Temperature}

The wastewater temperature at the running stage is set at $25-35^{\circ} \mathrm{C}$ so that microorganisms can grow optimally. While the results obtained in reactors $\mathrm{A}, \mathrm{B}, \mathrm{C}$ ranged from 28.1 to $30.8^{\circ} \mathrm{C}$ and was still included in the optimum temperature. The wastewater temperature must be maintained or higher than the optimum temperature range so that microorganisms can grow faster. In comparison, the $\mathrm{pH}$ of the wastewater was measured and obtained the results of 6.5 - 7.5. However, according to Hartemink (2012), the $\mathrm{pH}$ of Andosol soil is usually low and ranges from 4.8 to 6.o. Therefore the $\mathrm{pH}$ of the wastewater becomes acidic. Even so, these bacteria can still grow in the $\mathrm{pH}$ range of 4-9 (Tchobanoglus et al., 2003).

\subsubsection{COD Reduction Results}

COD removal in reactor A fluctuated until day 12. This can be caused by bacteria that grow on the surface of the SMB, not evenly to the bottom layer. So that the biofilm formed is not evenly distributed in each layer of SMB. However, after day 12, COD removal began to stabilize. The average COD removal efficiency is $75 \%$. Just like reactor A, the COD reduction efficiency in reactor B also fluctuated. From the graph in Figure iv, reactor B could not determine the stable state because it experienced a drastic decrease and increase. The average efficiency of COD removal in reactor B is $74 \%$.

In contrast, reactor $C$ is volatile and has an average removal efficiency of $76 \%$. The COD removal efficiency in reactor B is the lowest compared to reactors A and C. This is because bamboo does not act as an adsorbent and is used as a medium for attaching bacteria. So, reactor B, which acts as an adsorbent only andosol soil. In reactors $\mathrm{A}$ and $\mathrm{C}$, which operate as adsorbents, are andosol soil and activated charcoal. However, reactor $C$ had a higher COD removal efficiency than reactor A because the biofilm attached to the $\mathrm{C}$ medium was thicker. The bacteria that stick to it are getting more viscous because of the bamboo media used as a place to stick.

The SMB layer can absorb organic contaminants, further broken down by microorganisms attached to the permeable layer. According to Song et al. (2018), this can happen because the large surface and pore space in SMB and zeolite can make small particles of organic matter trapped. After that, the zeolite will darken by itself in the process of removing organic matter. Zeolite can absorb organic matter $96 \pm$ eight meq/10o g (Ho and Wang, 2015). Small pores and large surface area cause Andosol soil and activated charcoal to function well in removing COD concentrations. This can be explained because the more surface area, the more microorganisms grow to absorb organic contaminants. 


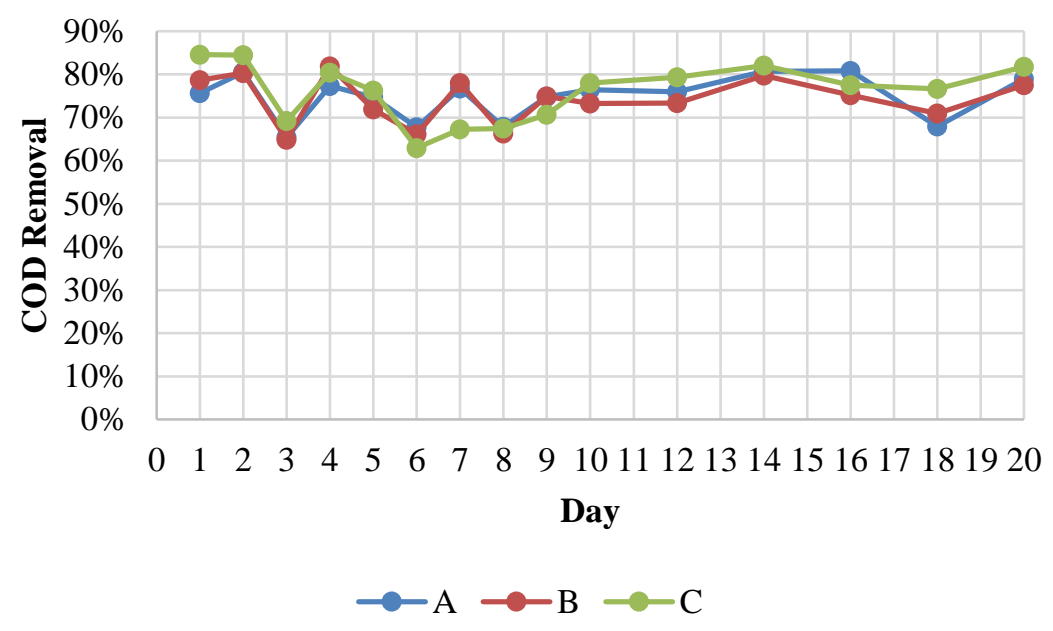

Figure 4. COD removal efficiency with MSL

\section{Conclusion}

Removal or migration of COD concentration in greywater using Multi Soil Layering (MSL) technology has been carried out and obtained results in reactor C (andosol soil, bamboo apus, activated charcoal), which has the highest average removal efficiency of $76 \%$. This can happen because there is andosol soil and activated charcoal, which acts as an adsorbent. In addition, the bacteria that absorb contaminants attached to the bamboo media are getting thicker-followed by reactor A (activated charcoal and andosol soil) with a removal efficiency of $75 \%$ and reactor B (bamboo apus and andosol soil) $74 \%$. The results obtained in reactors $\mathrm{A}, \mathrm{B}, \mathrm{C}$ ranged from 28.1 to $30.8^{\circ} \mathrm{C}$ and still included in the optimum temperature and $\mathrm{pH}$ in the range of 6.5-7.5.

\section{Acknowledgment}

This opportunity, thanks are addressed to the Department of Environmental Engineering, Faculty of Engineering, Diponegoro University for their assistance in this research.

\section{References}

An, C., Mcbean, E., Huang, G., Yao, Y., Zhang, P., Chen, X. \& Li, Y. 2016. Multi-soil-layering systems for wastewater treatment in small and remote communities. Journal of Environmental Informatics, 27, 131-144.

Anonymous. 2019. Peraturan Kementerian Dalam Negeri (Permendagri) tentang Perubahan Atas Peraturan Menteri Dalam Negeri Nomor 137 Tahun 2017 Tentang Kode Dan Data Wilayah Administrasi Pemerintahan. In: NEGERI, K. D. (ed.).

Asano, T., Burton, F. \& Leverenz, H. 2007. Water reuse: issues, technologies, and applications, McGrawHill Education.

Eriksson, E., Auffarth, K., Henze, M. \& Ledin, A. 2002. Characteristics of grey wastewater. Urban water, $4,85-104$.

Guan, Y.-D., Xu, D.-F., Chen, X., Luo, A.-C., Fang, H. \& Song, Y.-Z. 2014. Flow patterns of multi-soillayering systems. Desalination and Water Treatment, 52, 4165-4169.

Hartemink, A. 2012. Handbook of Soil Sciences. Wiley Online Library.

Ho, C.-C. \& Wang, P.-H. 2015. Efficiency of a multi-soil-layering system on wastewater treatment using environment-friendly filter materials. International Journal of Environmental Research and Public Health, 12, 3362-3380.

Noutsopoulos, C., Andreadakis, A., Kouris, N., Charchousi, D., Mendrinou, P., Galani, A., Mantziaras, I. \& Koumaki, E. 2018. Greywater characterization and loadings-physicochemical treatment to promote onsite reuse. Journal of Environmental Management, 216, 337-346. 
Pawestri, D. S., Budiono, Z. \& Abdullah, S. 2020. Efisiensi multi soil layering (MSL) dalam menurunkan kadar chromium heksavalen (cr6+) pada limbah cair sablon di Kaos Ngapak Kabupaten Banyumas Tahun 2020. Buletin Keslingmas, 39, 131-137.

Rahajeng, E. M., Sumiyati, S. \& Samudro, G. 2015. Pengaruh konsentrasi Chemical Oxygen Demand (COD) dan pH terhadap kinerja Granular Activated Carbon Dual Chamber Microbial Fuel Cells (GAC-DCMFCs). Jurnal Teknik Lingkungan, 4, 1-8.

Santoso, S. 2014. Limbah cair domestik: Permasalahan dan dampaknya terhadap lingkungan. Materi Penyuluhan Kepada Masyarakat Desa Pasinggangan, Kec. Banyumas.

Sato, K., Iwashima, N., Wakatsuki, T. \& Masunaga, T. 2011. Quantitative evaluation of treatment processes and mechanisms of organic matter, phosphorus, and nitrogen removal in a multi-soillayering system. Soil Science and Plant Nutrition, 57, 475-486.

Song, P., Huang, G., An, C., Shen, J., Zhang, P., Chen, X., Shen, J., Yao, Y., Zheng, R. \& Sun, C. 2018. Treatment of rural domestic wastewater using multi-soil-layering systems: Performance evaluation, factorial analysis and numerical modeling. Science of the Total Environment, 644, 536-546.

Suci, S. 2017. Aplikasi Zeolit dari Blotong dan Lempung untuk Mengadsorpsi Logam Berat Kromium $(\mathrm{Cr})$. Universitas Islam Negeri Alauddin Makassar.

Tchobanoglus, G., Burton, F. \& Stensel, H. D. 2003. Wastewater engineering: Treatment and reuse. American Water Works Association. Journal, 95, 201.

Vymazal, J. \& Březinová, T. 2016. Accumulation of heavy metals in aboveground biomass of Phragmites australis in horizontal flow constructed wetlands for wastewater treatment: a review. Chemical Engineering Journal, 290, 232-242.

Wei, C.-J. \& Wu, W.-Z. 2018. Performance of single-pass and by-pass multi-step multi-soil-layering systems for low- $(\mathrm{C} / \mathrm{N})$-ratio polluted river water treatment. Chemosphere, 206, 579-586.

Wu, Z., An, Y., Wang, Z., Yang, S., Chen, H., Zhou, Z. \& Mai, S. 20o8. Study on zeolite enhanced contact-adsorption regeneration-stabilization process for nitrogen removal. Journal of Hazardous Materials, 156, 317-326.

Ying, G., Xing, Y., Li, Z., Pan, J. \& Kuang, X. 2010. Advantages of psychrophiles in improving biotreatment efficiency of small size constructed wetlands during cold weather. Environmental progress \& sustainable energy, 29, 25-33.

Zaman, B. \& Oktiawan, W. 2020. Efficiency of multi soil layering (MSL) system in a household-scale wastewater treatment using environmentally friendly materials. Sustinere: Journal of Environment and Sustainability, 4, 33-42.

Zhang, P., Huang, G., An, C., Fu, H., Gao, P., Yao, Y. \& Chen, X. 2019. An integrated gravity-driven ecological bed for wastewater treatment in subtropical regions: process design, performance analysis, and greenhouse gas emissions assessment. Journal of Cleaner Production, 212, 1143-1153. 